Ice Nuclei in Soil Compromise Cold Hardiness of Hatchling Painted Turtles (Chrysemys picta) Author(s): Jon P. Costanzo, Jacqueline D. Litzgus, John B. Iverson, Richard E. Lee and Jr.

Source: Ecology, Vol. 81, No. 2 (Feb., 2000), pp. 346-360

Published by: Wiley

Stable URL: http://www.jstor.org/stable/177432

Accessed: 08-03-2016 14:01 UTC

Your use of the JSTOR archive indicates your acceptance of the Terms \& Conditions of Use, available at http://www.jstor.org/page/ info/about/policies/terms.jsp

JSTOR is a not-for-profit service that helps scholars, researchers, and students discover, use, and build upon a wide range of content in a trusted digital archive. We use information technology and tools to increase productivity and facilitate new forms of scholarship. For more information about JSTOR, please contact support@jstor.org. 


\title{
ICE NUCLEI IN SOIL COMPROMISE COLD HARDINESS OF HATCHLING PAINTED TURTLES (CHRYSEMYS PICTA)
}

\author{
Jon P. Costanzo, ${ }^{1,3}$ Jacqueline D. Litzgus, ${ }^{1}$ John B. Iverson, ${ }^{2}$ And Richard E. Lee, JR. ${ }^{1}$ \\ 'Department of Zoology, Miami University, Oxford, Ohio 45056 USA \\ ${ }^{2}$ Department of Biology, Earlham College, Richmond, Indiana 47374 USA
}

\begin{abstract}
Hatchling painted turtles (Chrysemys picta) commonly overwinter within their natal nests and survive exposure to temperatures as low as $-12^{\circ} \mathrm{C}$ by supercooling. We report that the supercooling capacity of hatchling $C$. picta is reduced by direct contact with nest soil which, in samples from northwestern and north-central Nebraska, Indiana, and Ontario, contained potent ice nuclei active in the range of $-3.5^{\circ}$ to $-5^{\circ} \mathrm{C}$. These nuclei were sensitive to autoclaving and extractable in water. The supercooling capacity of $C$. picta hatched in native nest soil, or hatched in sterilized vermiculite (which lacks waterextractable nuclei), and subsequently exposed to nest soil, was reduced by $\sim 10^{\circ} \mathrm{C}$ relative to control turtles that were hatched and reared in sterilized vermiculite. The effect of these nuclei was potentiated by the presence of environmental moisture, although even transient exposure to dry nest soil markedly reduced supercooling capacity in $\sim 50 \%$ of the turtles. Unlike turtle species that hibernate underwater (Sternotherus odoratus, Chelydra serpentina, Apalone spinifera), hatchlings of $C$. picta exhibited an extraordinary capacity for supercooling (temperature of crystallization, $-16^{\circ}$ to $-20^{\circ} \mathrm{C}$ ) when cooled in isolation from external ice nuclei. However, hatchlings of these four species were equally susceptible to inoculation by suspensions of the ice-nucleating bacterium, Pseudomonas syringae. Indirect evidence suggests that the soil nuclei are associated with such microbes. Nucleating activity was higher in soil collected within nests than in soil collected at the same depth, adjacent to these nests. Differences in the activities of ice nuclei in nesting soils may account for geographic and local variation in winter survival of hatchling C. picta. Our finding that similar agents occur in various other terrestrial habitats in central North America suggests that such nuclei may pose a formidable challenge to the overwintering survival of ectothermic animals that rely on supercooling to withstand frost exposure.
\end{abstract}

Key words: Chrysemys picta; freeze tolerance; geographic variability; hatchling turtle; ice nucleator; microenvironment; soil; supercooling; winter survival.

\section{INTRODUCTION}

Observations of hatchling painted turtles (Chrysemys picta) hibernating within natal nests have provoked considerable interest in the cold hardiness of this species. At northern latitudes, hatchlings overwintering in nests may be transiently exposed to temperatures as low as $-5^{\circ}$ to $-11^{\circ} \mathrm{C}$ (Woolverton 1963, DePari 1988, Storey et al. 1988, Packard et al. 1989, Costanzo et al. 1995b, Packard 1997). Exceptional cold hardiness in this species was initially attributed to supercooling (Bailey 1949, Bleakney 1963, Breitenbach et al. 1984), a phenomenon in which body fluids remain liquid at a body temperature $\left(T_{\mathrm{b}}\right)$ at or below the equilibrium freezing/melting point $\left(F P_{\text {eq }}\right)$ of tissues, approximately $-0.6^{\circ} \mathrm{C}$ for C. picta (Churchill and Storey 1992). This view is advocated by some contemporary workers (see Packard et al. 1997b, and references therein). Recent work has also shown that hatchling $C$. picta can survive the freezing of their tissues for at least 11d, although

Manuscript received 2 January 1998; revised 4 September 1998; accepted 8 December 1998; final version received 11 January 1999.

3.E-mail: costanjp@muohio.edu frozen turtles cannot tolerate a $T_{\mathrm{b}}$ lower than approximately $-4^{\circ} \mathrm{C}$ (Storey et al. 1988, Claussen and Zani 1991, Churchill and Storey 1992, Costanzo et al. $1995 b$ ). Whereas either mechanism may permit survival during mild cooling episodes, supercooling alone enables turtles to tolerate exposure to the extreme temperatures occurring in nests during some winters (Costanzo et al. 1995b, Packard and Packard 1995).

Supercooling capacity of vertebrate ectotherms studied under idealized laboratory conditions (i.e., in the absence of external ice nuclei) is influenced by body size, water content, osmotic concentration of body fluids, abundance of endogenous ice-nucleating agents, and cooling rate (Costanzo and Lee 1995). The supercooling capacity of hatchling C. picta is inferred from the supercooling point (SCP), or as it is more appropriately termed, the temperature of crystallization $\left(T_{\mathrm{c}}\right)$. Values of $T_{\mathrm{c}}$ reported for these turtles range from less than $-8^{\circ} \mathrm{C}$ (Packard and Packard 1995, Packard and Janzen 1996, Packard et al. $1997 b$ ) to more than $-3^{\circ} \mathrm{C}$ (DePari 1988, Storey et al. 1988, Claussen and Zani 1991, Storey et al. 1991, Churchill and Storey 1992, Costanzo et al. 1995b). Noting that the turtles that su- 
percooled extensively had been hatched and reared in vermiculite in the laboratory, and that the other turtles had hatched in soil within natural nests, we questioned whether the discrepant reports of supercooling capacity might reflect differences in turtle handling procedures.

In a preliminary test of this hypothesis, we obtained eggs from a single $C$. picta from Cherry County, Nebraska, $\sim 24 \mathrm{~km}$ from Valentine National Wildlife Refuge (VNWR; $43^{\circ} \mathrm{N}, 101^{\circ} \mathrm{W}$ ), the principal source of turtles studied by G. C. Packard and colleagues. We hatched and reared these turtles on damp vermiculite ( $2.0 \mathrm{~g}$ water/g vermiculite) in the laboratory. Following a protocol that fosters extensive supercooling of turtles from this population (Packard and Packard 1995), neonates $(n=5)$ were cold acclimated, carefully cleaned of adherent vermiculite, and air dried of surface moisture. Two hatchlings were then buried and held for 24 $\mathrm{h}$ in damp sandy soil ( $0.12 \mathrm{~g}$ water/g soil) that had been collected from occupied C. picta nests during mid-October 1993, in west-central Nebraska (Costanzo et al. $1995 b$ ). In supercooling trials, these turtles nucleated at strikingly higher temperatures $\left(T_{\mathrm{c}}:-1.6^{\circ}\right.$ and $\left.-3.0^{\circ} \mathrm{C}\right)$ than the remaining turtles $\left(T_{\mathrm{c}}:-11.9^{\circ},-13.4^{\circ}\right.$, and $\left.-14.5^{\circ} \mathrm{C}\right)$, that had been exposed only to vermiculite. We thus concluded that exposure to nest soil may diminish supercooling capacity of hatchling $C$. picta.

We further questioned whether the supercooling capacity of hatchling $C$. picta exposed to nest soil was reduced owing solely to inoculation by ice, which may readily occur in these turtles (Costanzo et al. 1995b, Packard and Packard 1995, Packard and Janzen 1996, Packard and Packard 1997, Packard et al. 1997b), and other ectotherms (Salt 1965, Bale 1987, Bale et al. 1989 , Lee 1991), or whether other nuclei were involved. Despite the fact that they contained much less water, samples of the damp nest soil nucleated at higher temperatures than the vermiculite $\left(T_{\mathrm{c}}\right.$, mean $\pm 1 \mathrm{SE}=$ $-3.9^{\circ} \pm 0.1^{\circ} \mathrm{C} ; n=10$ vs. $-5.4^{\circ} \pm 0.4^{\circ} \mathrm{C} ; n=10$, respectively; Student's $t$ test: $t=3.7$, df $=18, P=$ 0.002 ). The $T_{\mathrm{c}} \mathrm{s}$ of bulk soil samples hydrated to various levels were markedly higher than values predicted from the volumes of water they contained, suggesting that nest soil contained potent ice nuclei (Fig. 1).

Nest soil potentially harbors a suite of ice nuclei, such as mineral particulates (e.g., quartz and silicates; Mason and Maybank 1958, Roberts and Hallett 1968, Shen et al. 1977), the organic crystalloids liberated during decay processes (Power and Power 1962, Fukuta 1966), and certain bacteria and fungi (Lee et al. 1993, Vali 1995). Additional tests revealed that: (1) autoclaving the nest soil, which would destroy any constituent organic nuclei (Vali 1995), diminished (but did not eliminate) its nucleating activity (Fig. 1); and (2) the autoclave-sensitive agent could be transferred to washings prepared by refluxing a mixture of nest soil and sterilized water. In contrast, the nucleating activity expressed in bulk samples of vermiculite (see also $\mathrm{Ku}$ -

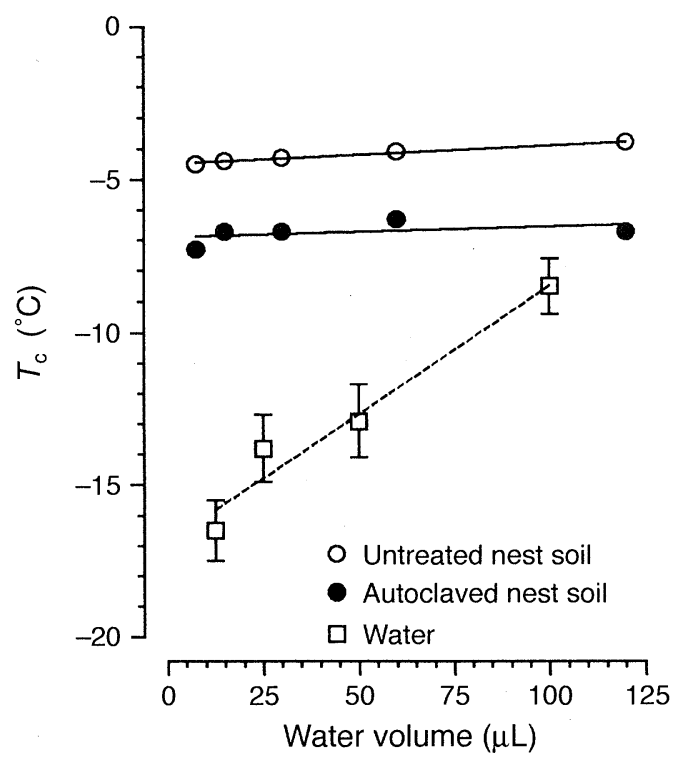

FIG. 1. Ice-nucleating activity, as represented by the temperature of crystallization $\left(T_{\mathrm{c}}\right)$, of soil collected from nests of the painted turtle (Chrysemys picta), relative to sterilized, deionized water. Samples $\left(100 \mathrm{~mm}^{3}\right)$ of untreated or autoclaved soil were hydrated to the desired level, gently packed by low-speed centrifugation in $0.5-\mathrm{mL}$ polyethylene tubes, and cooled at $-0.5^{\circ} \mathrm{C} / \mathrm{min}$. The temperature during cooling was monitored using a thermocouple attached to the exterior of each tube. Each point represents the mean $( \pm 1 \mathrm{SE})$ of $n=$ 10 replicates/group. Lines were fitted using simple regression (untreated nest soil, $r^{2}=0.99, P<0.001$; autoclaved nest soil, $r^{2}=0.19, P<0.46$; water, $r^{2}=0.96, P<0.05$ ).

mai 1976, Shen et al. 1977) was unaffected by autoclaving and not extractable in water.

Collectively, our preliminary data suggested that soil in which $C$. picta hatches and overwinters may contain water-extractable, autoclave-sensitive nuclei that may influence the supercooling capacity of turtles. Research presented in this report further explores the role of environmental ice nuclei, particularly those that are extractable in water, in the cold hardiness of hatchling C. picta. Specifically, we determined the effect on supercooling capacity of hatching and rearing C. picta in native nest soil, of briefly exposing turtles hatched in vermiculite to nest soil, and of exposing hatchlings of C. picta and other turtle species to ice-nucleating bacteria. We also investigated the geographic and local distribution of water-extractable ice nuclei (WEIN) in turtle nesting areas and other habitats, and characterized these agents. To make our research broadly applicable to this wide-ranging species (Ernst et al. 1994), we studied nesting soils and hatchling $C$. picta from several locales, including ones used in previous studies of cold hardiness.

\section{Materials And Methods}

All turtles used in this study were hatched from eggs collected from the wild and incubated in the laboratory. 
Eggs were collected on 25 August 1996, approximately 8 wk after they were laid, from four $C$. picta nests ( $n$ = 5-7 eggs/nest) at Wolf Howl Pond, Algonquin Provincial Park, Ontario, Canada (APP; $45^{\circ} \mathrm{N}, 78^{\circ} \mathrm{W}$ ). Turtles from this population were previously investigated by K. B. Storey and co-workers (Storey et al. 1988, Storey et al. 1991, Churchill and Storey 1992). Eggs were also obtained in June 1996 by administering oxytocin (Etchberger et al. 1992) to gravid C. picta from Dewart Lake, Kosciusko County, Indiana (DL; $41^{\circ} \mathrm{N}, 85^{\circ} \mathrm{W}$ ). The typical body mass of hatchling $C$. picta was $4.3 \mathrm{~g}$ (carapace length, $27 \mathrm{~mm}$; plastron length, $25 \mathrm{~mm}$ ). For comparison, we also studied hatchlings of the musk turtle (Sternotherus odoratus), snapping turtle (Chelydra serpentina), and spiny softshelled turtle (Apalone spinifera) that hibernate in aquatic habitats (Ernst et al. 1994) and are intolerant of freezing (Costanzo et al. 1995b; J. Costanzo, J. Iverson, and R. Lee, unpublished data). Eggs of S. odoratus and $C$. serpentina from DL, and of $A$. spinifera from near Muscatatuck National Wildlife Refuge $\left(38^{\circ} \mathrm{N}, 85^{\circ}\right.$ W), Jennings County, Indiana, were obtained during June 1996 from females that were administered oxytocin.

We studied nucleating activity in soil collected from extant $C$. picta nests, or at an equivalent depth $(\sim 10$ $\mathrm{cm}$ ) at sites where $C$. picta is known to nest. The principal sample used in these studies (GL-1), which was also used in the preliminary work described in the Introduction, was collected near Gimlet Lake (GL; $41^{\circ}$ $\mathrm{N}, 102^{\circ} \mathrm{W}$ ), at Crescent Lake NWR, Garden County, Nebraska (Costanzo et al. 1995b). These samples were collected in mid-October 1993 from 12 nests occupied by hatchling $C$. picta and stored at $5^{\circ} \mathrm{C}$ in a covered container for 30-45 mo before use. Additional samples (GL-2) were collected at GL in September 1996 from seven sites, each $<0.5 \mathrm{~m}$ from a nest constructed the previous year. Soil was sampled at APP in late August 1996 from the same four nests from which eggs were collected, and also from satellite locations $3 \mathrm{~m}$ to the west and east of each nest. We collected soil at DL in September 1996 from three nesting sites, and in June 1996 from a single nesting site at Valentine NWR. Soil samples were kept damp (0.025 g water/g dry soil), and chilled $\left(5^{\circ} \mathrm{C}\right)$ in covered containers, and (excepting GL-1) were tested for nucleating activity within 5 mo of collection.

\section{Turtle incubation, rearing, and cold acclimation}

Except where noted, eggs were incubated to hatching at $\sim 29^{\circ} \mathrm{C}$ in moist vermiculite $(1.0 \mathrm{~g}$ water/g vermiculite; approximately $-150 \mathrm{kPa})$. Hatchlings were transferred to plastic rearing boxes containing damp vermiculite $(0.5 \mathrm{~g}$ water/g vermiculite; approximately $-350 \mathrm{kPa})$, kept in darkness, and denied food and free water. Beginning in mid-September, they were cold acclimated by reducing environmental temperature from $20^{\circ}$ to $5^{\circ} \mathrm{C}$, in three decrements of $5^{\circ} \mathrm{C}$, over a 2 -mo period; this regimen was based on field data for $\mathrm{Ne}$ braska $C$. picta (Costanzo et al. 1995b). Turtles were then held at $5^{\circ} \mathrm{C}$ until used in experiments during late winter (February-March).

\section{Measuring supercooling capacity of hatchling turtles}

Before use in the supercooling trials, turtles were removed from their holding boxes, cleaned of adherent vermiculite using a sterilized blunt spatula and a finehaired brush, and kept in dry, loosely-covered cups for $24 \mathrm{~h}\left(5^{\circ} \mathrm{C}\right.$, in darkness) to permit moisture to evaporate from the body surfaces. Supercooling capacity was determined by cooling hatchlings at a uniform rate until their tissues spontaneously froze. In natural nests, hatchling $C$. picta cool slowly (maximum rates typically $<-1^{\circ} \mathrm{C} / \mathrm{h}$; Costanzo et al. 1995b). However, to expedite the collection of data, we elected to cool turtles more rapidly. A pilot study (using hatchling $C$. picta from DL) showed that the mean $T_{\mathrm{c}}$ of turtles cooled at $-10^{\circ} \mathrm{C} / \mathrm{h}\left(\right.$ mean $\pm 1 \mathrm{SE}=-18.2^{\circ} \pm 0.4^{\circ} \mathrm{C}$; $n=8)$ did not differ (Student's $t$ test: $t=1.6$, df $=$ $12, P=0.1)$ from that of turtles cooled at $-0.2^{\circ} \mathrm{C} / \mathrm{h}$ $\left(-17.3^{\circ} \pm 0.2^{\circ} \mathrm{C} ; n=6\right)$. These groups did not differ in mean body mass $(t=1.2, \mathrm{df}=12, P=0.3)$, carapace length $(t=1.4$, df $=12, P=0.2)$, plastron length $(t$ $=1.1, \mathrm{df}=12, P=0.3)$, or water content $(t=0.7$, $\mathrm{df}=12, P=0.5)$. We thus justified the use of the higher rate in subsequent trials.

Turtle $T_{\mathrm{c}}$ was determined by cooling hatchlings until each had produced an exotherm, the nearly instantaneous rise in temperature associated with the onset of tissue freezing. Turtles were placed individually in a narrow plastic tube, instrumented with the junction of a 30-gauge, copper/constantan thermocouple (parts from Omega, Stamford, Connecticut) positioned against the plastron, and insulated by loosely filling the air space above with plastic foam (Costanzo et al. $1995 b$ ). Tubes were then placed vertically into an insulated jar submerged in a refrigerated ethanol bath (Forma Scientific, Marietta, Ohio, USA). After turtles had reached thermoequilibrium at $\sim 0^{\circ} \mathrm{C}$, the bath thermostat was adjusted to initiate cooling. During cooling, hatchling $T_{\mathrm{b}}$ was logged at 30 -s intervals on a chart recorder (Omega RD3752, Stamford, Connecticut, USA). After all turtles had begun to freeze, they were removed from the bath, measured for carapace and plastron lengths and body mass, and euthanized by quick freezing to $-80^{\circ} \mathrm{C}$. Moisture content of each carcass was determined by drying at $65^{\circ} \mathrm{C}$ to constant mass.

Supercooling capacity of $\mathrm{C}$. picta hatched and reared in native soil vs. vermiculite. - The purpose of this experiment was to determine whether the supercooling capacity of hatchling $C$. picta is influenced by prolonged exposure to native nest soil. We incubated 13 eggs (APP) in damp soil (0.025 $\mathrm{g}$ water/g soil, as per field water content; $\sim 0 \mathrm{kPa}$ ) collected from their respective nests, and seven others, whose shells were 
rinsed with sterilized water and wiped to remove traces of soil, in sterilized, damp vermiculite. After hatching, shell fragments and embryonic membranes were removed from the boxes containing vermiculite, whereas, to better simulate natural conditions, they were left within the boxes containing nest soil. Hatchlings were kept on these substrates throughout the cold-acclimation regimen. In midwinter, hatchlings were cleaned of adherent particulates, air dried of surface moisture, and cooled inside dry, plastic tubes to determine their $T_{\mathrm{c}} \mathrm{s}$. Ice-nucleating activity of the incubation/rearing substrates was determined at this time (see Measuring activity of water-extractable ice nuclei).

Supercooling capacity of hatchling C. picta briefly exposed to nest soil.-Two experiments were conducted in which hatchlings were briefly exposed to nest soil (GL-1) and then tested for supercooling capacity. In both experiments, hatchling $C$. picta (DL) were removed from their rearing boxes, cleaned of adherent vermiculite, air dried of surface moisture, and placed in groups $(n=3-5)$ within loosely covered plastic cups. The cups were partially filled with GL-1 taken directly from its storage container ("untreated") or autoclaved to diminish its nucleating activity. Hatchlings remained covered by the soil for $48 \mathrm{~h}$ before they were used in supercooling trials.

In the first experiment, we compared $T_{\mathrm{c}}$ values of hatchlings exposed to untreated $(n=11)$ or autoclaved $(n=11)$ soil that had been thoroughly dried by evaporation at $5^{\circ} \mathrm{C}$. Supercooling trials were conducted by cooling turtles immersed in a column $(15-20 \mathrm{~mL})$ of the same soil in which they had been incubated. In these trials, a thermocouple placed adjacent to each animal invariably detected its exotherm. To provide estimates of maximal supercooling capacity (i.e., in the absence of external ice nuclei), $T_{\mathrm{c}} \mathrm{s}$ were determined for additional hatchlings $(n=14)$ that were removed from their rearing boxes, cleaned of adherent vermiculite, air dried of surface moisture for $24 \mathrm{~h}$, and cooled inside dry, plastic tubes.

In the second experiment, we investigated the effect of environmental moisture in potentiating the soil nuclei by comparing $T_{\text {c }}$ values for hatchling $C$. picta exposed to untreated $(n=5)$ or autoclaved $(n=5)$ nest soil hydrated to different levels. Turtles were initially exposed to nest soil moistened with sterilized, deionized water $(0.05 \mathrm{~g}$ water/g soil), and then tested for supercooling capacity (without being cleaned) inside dry, plastic tubes. Having survived the supercooling trials, these turtles were cleaned of adhering soil particles, permitted to recover at $5^{\circ} \mathrm{C}$, in darkness, for 48 $\mathrm{h}$, and then reused in an additional test to determine their supercooling capacity after exposure to drier soil (0.01 g water/g soil). To prevent cross contamination, turtles were assigned to the same soil treatment groups (untreated or autoclaved) as initially used. We assumed that responses of the hatchlings in the second trial would not be influenced by the brief chilling they re- ceived in the first trial (Salt 1965). The quantity of soil adhering to turtles during the final supercooling test was determined by weighing the soil recovered from oven-dried $\left(65^{\circ} \mathrm{C}\right)$ carcasses.

Supercooling capacity of hatchling turtles exposed to ice-nucleating bacteria.-The purpose of this experiment was to determine whether the supercooling capacity of hatchling turtles can be influenced by exposure to ice-nucleating bacteria, which commonly occur in habitats similar to the ones in which $C$. picta overwinters. Turtles were exposed to a preparation of killed, lyophilized Pseudomonas syringae and inactive fillers and conditioners that is commonly used in commercial snow-making applications (Genencor, Rochester, New York, USA). Owing to its stability and uniformity of nucleation activity $\left(\sim 1.7 \times 10^{11}\right.$ nuclei/g), this preparation was preferred to live microbial cultures. Hatchling $C$. picta from DL were removed from their rearing boxes, cleaned of adherent vermiculite, and air dried before being placed in groups $(n=3-5)$ within loosely covered plastic cups. The cups were partially filled with vermiculite that had been sterilized and moistened $(0.5 \mathrm{~mL} / \mathrm{g}$ vermiculite $)$ with either $P$. syringae suspension $(1.0 \mathrm{mg} / \mathrm{mL}$ sterilized, deionized water) or sterilized, deionized water. Hatchlings remained covered by vermiculite for $1 \mathrm{wk}$, after which they were cleaned of adherent particles, air dried, and cooled in air within dry, plastic tubes. For comparison, parallel experiments were conducted using hatchlings of $S$ odoratus, A. spinifera, and C. serpentina.

\section{Measuring activity of water-extractable ice nuclei}

The activity of WEIN was represented by mean $T_{\mathrm{c}}$ of washings prepared by vortexing nest soil (or other material) and sterilized, deionized water for $60 \mathrm{~s}$ and sedimenting the particulates by centrifugation $(540 \mathrm{~g})$. The resulting supernatant was expressed through a 5$\mu \mathrm{m}$ disk filter and held on ice in a microcentrifuge tube until assayed. To avoid excessive dilution of the nuclei, all samples were washed with a small amount of water, which, beyond that absorbed by the sample, yielded the minimum volume $(\sim 150 \mu \mathrm{L})$ of washing needed for assay. Washings of all soils were prepared by mixing $0.5 \mathrm{~g}$ water with $1.0 \mathrm{~g}$ soil. Preparing washings of less dense/more absorbent substrates required the use of relatively more water (up to $4.0 \mathrm{~g}$ water/g, for vermiculite).

A $10-\mu \mathrm{L}$ aliquot of washing was drawn into a $20-$ $\mu \mathrm{L}$ glass microcapillary tube, such that the fluid column was bounded by equal volumes of air, and the ends of the tube were sealed with clay. The junction of a 36-gauge copper/constantan thermocouple was taped to the center of the tube and the sample was inserted into a 20 -mL test tube submerged in a refrigerated ethanol bath (RTE140, Neslab, Portsmouth, New Hampshire, USA). After equilibrating at $\sim 0^{\circ} \mathrm{C}$, the sample was cooled at $1.5^{\circ} \mathrm{C} / \mathrm{min}$ until it produced an exotherm. We tested 12 replicates from each washing, 
and two washings were prepared from each sample; thus, the mean $T_{\mathrm{c}}$ representing each sample was based on $n=24$ values. Deionized water, filters, utensils, and vessels used in preparing the washings were autoclaved prior to use. The presence of WEIN in the substrates was determined by comparing the mean $T_{\mathrm{c}}$ of substrate washings with that of sterilized, deionized water. Sensitivity of the nuclei to autoclaving, a treatment that decreases the activity of organic nuclei (Vali 1995), was assessed by measuring the activity of washings prepared from autoclaved samples.

Geographic and local distribution of water-extractable ice nuclei in turtle nesting soils.-We assayed soils used for nesting by $C$. picta in west-central Nebraska (GL-1, GL-2), north-central Nebraska (VNWR), Indiana (DL), and Ontario (APP) for the presence of WEIN. Data were gathered for soil collected from extant nests or nesting sites, as well as for homogenous mixtures of soil, combined in equal amounts from nests or nesting sites, representing each source locale. Soil texture was estimated for each pooled sample. Organic content was determined for both pooled and individual samples by incinerating soil at $550^{\circ} \mathrm{C}$ in a furnace (1400, Thermolyne, Dubuque, Iowa, USA).

Characterization of water-extractable ice nuclei in turtle nesting soils.-The relative abundance of WEIN in GL-1 was determined by assaying the activity in serial dilutions of a washing prepared from this material. Clues to the identity of the nuclei were sought by subjecting additional washings of GL-1 to various tests intended to isolate or deactivate them, including filtration and centrifugation, and denaturization by thermal, chemical, and enzymatic processes. For comparison, identical tests were performed on a suspension of $P$. syringae preparation.

Hypothesizing that WEIN may be associated with an ice-nucleating microorganism, we incubated nest soil at progressively decreasing temperatures to determine whether cold exposure would enhance nucleating activity, such as occurs with some microbes (Rogers et al. 1987). A mixture of soil pooled from four eggcontaining nests (APP) was enclosed in a glass vial and incubated, in darkness, following the schedule for stepacclimating turtles to low temperature (i.e., from $20^{\circ}$ to $5^{\circ} \mathrm{C}$, in three decrements over a 2 -mo period). After being held at $5^{\circ} \mathrm{C}$ for $3 \mathrm{mo}$, the sample was divided and the subsamples were thereafter kept at $-2.5^{\circ}$ or $10^{\circ} \mathrm{C}$ for $4 \mathrm{wk}$. Activity of the WEIN in the sample was measured at the end of each interval of the acclimation regimen.

Occurrence of water-extractable ice nuclei in natural habitats.-Our discovery of potent WEIN in nesting soils used by $C$. picta in several locations in central North America prompted us to survey other habitats in this region, including agricultural fields, a deciduous wood lot, a sphagnum bog, and two ponds. We also screened materials commonly used in construction and horticultural applications (sand, vermiculite, clay, peat) for presence of WEIN. Samples were kept in closed containers at $5^{\circ} \mathrm{C}$ for at least 1 mo before testing. Assays of nucleating activity were conducted using sample washings (and liquid samples) that were passed through a $5 \mu \mathrm{m}$ filter.

\section{Statistical inferences}

Sample means were compared using $t$ tests or ANOVA, with multiple contrasts determined by Bonferroni test ( $<8$ comparisons), Scheffé ( $\geq 8$ comparisons), or Dunnett's test (comparison against control value). Significance of statistical analyses was accepted at $P<$ 0.05 . Mean values are reported $\pm 1 \mathrm{se}$. Hatchlings used in supercooling trials were matched for body mass across all treatment groups within each experiment; post hoc analyses confirmed that no differences existed among the groups with respect to body fresh mass, dry mass, carapace length, plastron length, or water content; thus, in all cases variation in mean $T_{\mathrm{c}}$ was ascribed with confidence to differences in the experimental treatments.

\section{RESULTS}

\section{Supercooling capacity of C. picta hatched and} reared in native soil vs. vermiculite

Eggs collected from APP and incubated in native nest soil or sterilized vermiculite hatched in early September. The mean $T_{\mathrm{c}}$ of hatchlings incubated and maintained in soil, $-9.4^{\circ} \pm 0.9^{\circ} \mathrm{C}(n=13)$, was markedly higher (Student's one-tailed $t$ test: $t=4.0, \mathrm{df}=18, P$ $=0.0008$ ) than that of turtles hatching and subsequently kept in vermiculite, $-15.9^{\circ} \pm 1.5^{\circ} \mathrm{C}(n=7)$. Whereas washings of the vermiculite lacked nucleating activity $\left(T_{c},-17.9^{\circ} \pm 0.5^{\circ} \mathrm{C}\right)$, the nest soil contained potent WEIN $\left(-3.6^{\circ} \pm 0.1^{\circ} \mathrm{C}\right)$. Because both groups of turtles were tested in the absence of external ice nuclei (i.e., they were cleaned of adherent particulates, air dried of surface moisture, and cooled in otherwise empty, dry tubes), we ascribed the higher $T_{\mathrm{c}}$ of hatchlings maintained in nest soil to their prior exposure to the WEIN in the soil.

\section{Supercooling capacity of hatchling C. picta briefly exposed to nest soil}

We compared $T_{\mathrm{c}}$ values for hatchlings that were briefly exposed to dry nest soil, either untreated or autoclaved, to those for control turtles, that were kept in sterilized vermiculite (Fig. 2). Control data were normally distributed (Shapiro-Wilk: $W=0.9, P>0.1$ ) about a mean of $-18^{\circ} \mathrm{C}$. Of the hatchlings exposed to autoclaved nest soil, most ( $73 \% ; n=8$ of 11$)$ supercooled to the same extent as controls, although the results for three turtles rendered the data set nonnormal ( $W=0.8, P=0.006$ ). Notwithstanding these outliers, the distribution of data for this group did not differ (Kolmogorov-Smirnov: $D=56, P>0.1$ ) from that of controls. The distribution of $T_{\mathrm{c}}$ values for hatchlings 


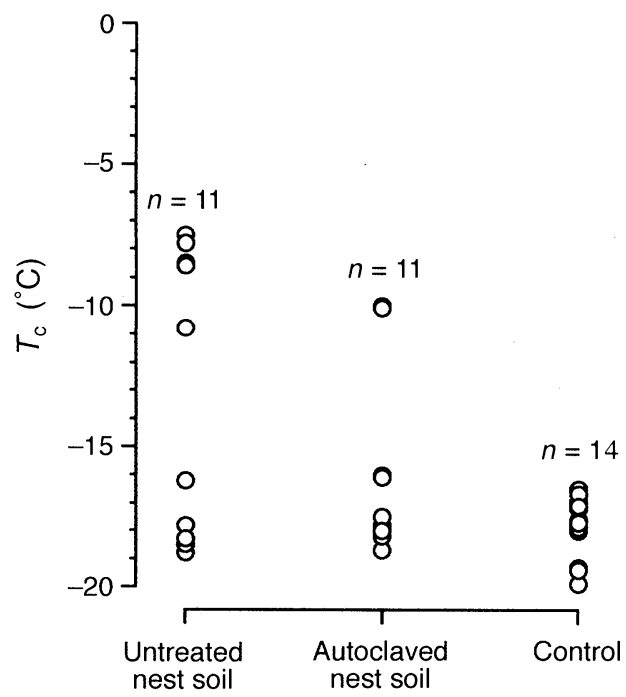

FIG. 2. Supercooling capacity of hatchling painted turtles (Chrysemys picta) immersed in dry, untreated nest soil containing active, water-extractable ice nuclei (untreated), or dry, autoclaved nest soil. Data for turtles exposed to soil are shown relative to values for control turtles that were kept on sterilized vermiculite, cleaned of adherent particulates, air dried of surface moisture, and cooled in otherwise empty, dry tubes (i.e., isolated from external ice nuclei). Each point represents the temperature of crystallization $\left(T_{\mathrm{c}}\right)$ of one turtle.

exposed to untreated nest soil were also nonnormal ( $W$ $=0.8, P=0.008$ ) and markedly bimodal: extensive supercooling occurred in about half the sample, whereas the remainder nucleated at approximately $-9^{\circ} \mathrm{C}$ (Fig. 2). Although the distributions of $T_{c}$ values for turtles exposed to untreated and autoclaved soil did not differ $(D=44, P>0.1)$, results for the former, but not for the latter, differed from those of controls $(D=84, P$ $=0.04$ ). We concluded that even brief exposure to dry nest soil, containing WEIN but no moisture, may markedly influence supercooling capacity of some hatchlings.

The effect of WEIN on the supercooling capacity of hatchling $C$. picta was also investigated in the presence of environmental moisture (Fig. 3). Turtles exposed to untreated soil containing active nuclei froze at higher temperatures than turtles exposed to autoclaved nest soil. This was the case in experiments using soil hydrated to either $0.05 \mathrm{~g}$ water/g soil (Student's one-tailed $t$ test: $t=2.1, \mathrm{df}=8, P=0.04$ ) or $0.01 \mathrm{~g}$ water $/ \mathrm{g}$ soil $(t=2.1, \mathrm{df}=8, P=0.04)$. Little supercooling occurred in (DL) turtles exposed to the wetter soil containing active ice nuclei. Similarly, inoculative freezing occurred at high temperature in the VNWR turtles exposed to damp nest soil containing potent ice nuclei, as described in the Introduction.

The degree of physical intimacy between the nest soil and the turtle was influenced by the water content of the soil. The amount of soil lodged in the axillary and inguinal pockets, and nuchal skin folds, of five turtles exposed to damp soil ( $0.01 \mathrm{~g}$ water/g soil) was equivalent to $3.8 \pm 1.2 \%$ of dry body mass. The two VNWR hatchlings used in our preliminary experiment were exposed to relatively wetter soil $(0.12 \mathrm{~g}$ water $/ \mathrm{g}$ soil) and harbored amounts equivalent to $32 \%$ and $39 \%$ of dry body mass.

\section{Supercooling capacity of hatchling turtles exposed to ice-nucleating bacteria}

In this experiment we determined whether the supercooling capacity of hatchling turtles may be influenced by exposure to microbial ice nuclei. Activity of the $P$. syringae suspension used in the experiment was $-2.7^{\circ} \pm 0.1^{\circ} \mathrm{C}$. Differences in the mean $T_{\mathrm{c}}$ of four species of turtles, exposed for $1 \mathrm{wk}$ to vermiculite moistened with sterilized water (control treatment) or $P$. syringae suspension, were analyzed using two-factor ANOVA (species $\times$ substrate treatment). Turtle $T_{\mathrm{c}}$ was strongly influenced by species $\left(F_{3,56}=41.0 ; P<\right.$ $0.0001)$ and substrate treatment $\left(F_{1,56}=60.7 ; P<\right.$ $0.0001)$, and these factors were strongly interactive $\left(F_{3,56}=15.2 ; P<0.0001\right.$; Fig. 4). Hatchling $C$. picta exposed to $P$. syringae nucleated at higher temperatures $\left(T_{\mathrm{c}}:-8.1^{\circ} \pm 1.0^{\circ} \mathrm{C} ; n=8\right)$ than the conspecific controls $\left(T_{\mathrm{c}}:-17.8^{\circ} \pm 0.5^{\circ} \mathrm{C} ; n=14\right)$. Similarly, the $T_{\mathrm{c}}$ of $S$. odoratus exposed to $P$. syringae, $-6.5^{\circ} \pm 0.9^{\circ} \mathrm{C}(n=$ $5)$, was higher than their control counterparts, $-11.4^{\circ}$ $\pm 0.6^{\circ} \mathrm{C}(n=10$; Fig. 4$)$. Exposure to $P$. syringae did not significantly increase the $T_{\mathrm{c}}$ of hatchling $A$. spinifera or $C$. serpentina, but these species supercooled

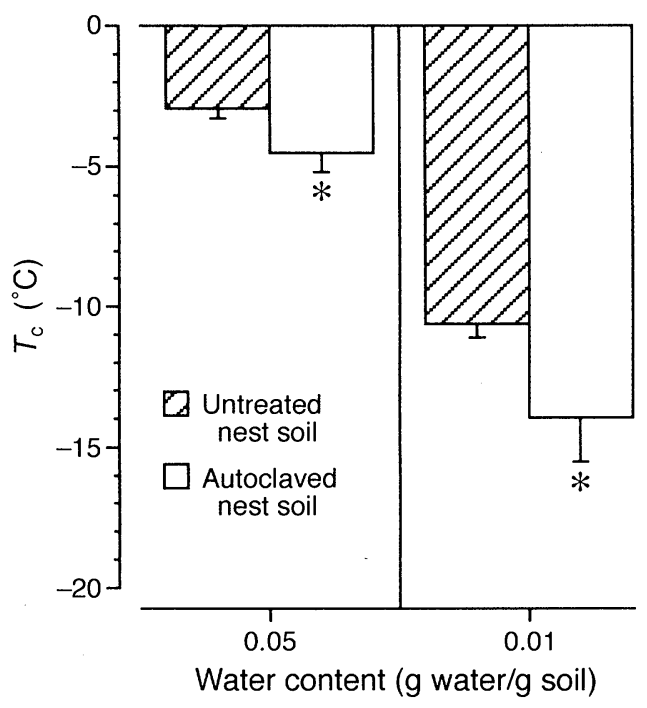

FIG. 3. Supercooling capacity of hatchling painted turtles (Chrysemys picta) determined after $48 \mathrm{~h}$ exposure to moist $(5 \%)$ or damp (1\%) nest soil containing active, water-extractable ice nuclei (untreated), or moist or damp autoclaved nest soil. Turtles were not cleaned of adherent soil particles prior to testing. Each column represents the mean ( $\pm 1 \mathrm{SE})$ temperature of crystallization $\left(T_{\mathrm{c}}\right)$ based on $n=5$ turtles/group. Asterisks denote that means in each pair differed significantly $(P<0.05)$. 


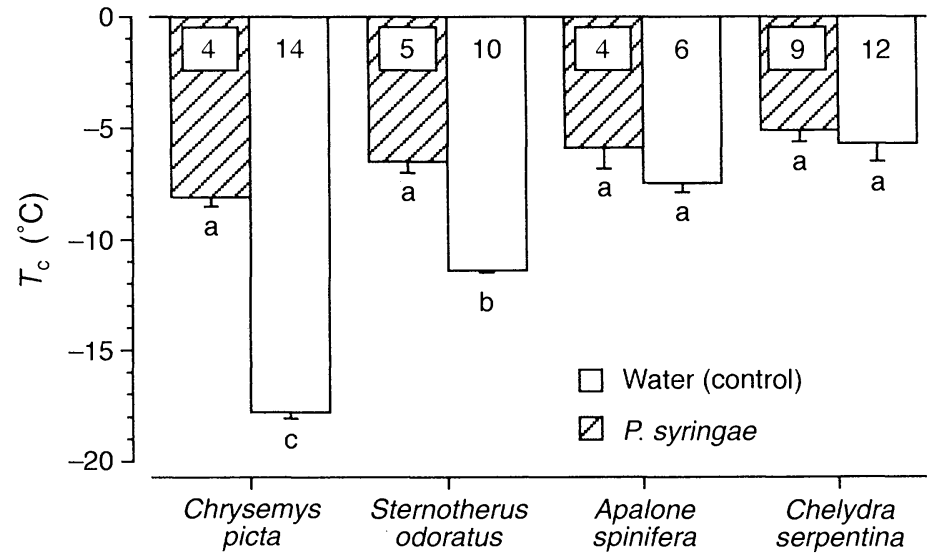

FIG. 4. Supercooling capacity of hatchlings of four turtle species determined after a 1-wk exposure to vermiculite moistened with either sterilized deionized water (control) or a suspension $(1.0 \mathrm{mg} / \mathrm{mL})$ of killed Pseudomonas syringae preparation. Turtles were cleaned of adherent particulates, air dried of surface moisture, and cooled in otherwise empty, dry tubes. Each column represents a group's mean temperature of crystallization $\left(T_{\mathrm{c}}\right)$; error bars represent $1 \mathrm{SE}$. Sizes of the samples are as shown. Means identified by different lowercase letters differed statistically (Scheffé test: $P<0.05$ ). minimally even in the absence of these nuclei. The mean $T_{\mathrm{c}}$ of hatchlings exposed to $P$. syringae ranged from $-8.1^{\circ} \pm 0.4^{\circ} \mathrm{C}(\mathrm{C}$. picta $)$ to $-5.1^{\circ} \pm 0.5^{\circ} \mathrm{C}(C$. serpentina), but did not differ among species (Fig. 4). Because the hatchlings in this experiment were air dried of surface moisture and cooled in the absence of external ice nuclei, $T_{\mathrm{c}}$ values for the control animals represent the maximum, innate capacity for supercooling.

\section{Geographic and local distribution of water-extractable nuclei in turtle nesting soils}

Soil from turtle nests and nesting sites in Nebraska, Indiana, and Ontario were predominantly sand and usually contained little organic matter $(0.5-5.9 \%$, mass per mass; Table 1). Pooled samples of soil, representing all of the individual samples collected at a particular locale, contained WEIN that were active in the range of $-3.6^{\circ}$ (APP) to $-5.3^{\circ} \mathrm{C}$ (VNWR). Activities varied among collecting locales $\left(F_{4,115}=88.9 ; P<0.0001\right)$.
No differences in nucleating activity were detected between GL-1 and GL-2 samples (Bonferroni test: $P=$ 0.2 ) despite the fact that GL-1 had been stored for up to 45 mo before use. Autoclaving the soil samples substantially reduced the activity of the constituent WEIN (Table 1).

Variation in ice-nucleating activity occurred among the individual soil samples collected at some of the nesting locales (Table 1). For example, activity in soil collected from inside four nests in Ontario (APP) ranged from $-11.2^{\circ}$ to $-3.4^{\circ} \mathrm{C}$ (ANOVA: $F_{3,91}=134.0$; $P<0.0001)$. Comparatively less variation occurred among the seven nesting sites (GL-2) in west-central Nebraska $\left(F_{6,157}=8.5 ; P<0.0001\right)$. On the other hand, soil collected from three nesting sites in Indiana (DL) contained nuclei of similarly high potency $\left(F_{2,69}=1.2\right.$; $P=0.3)$. Activity of WEIN in the individual soil samples was independent $\left(r^{2}=0.08 ; F_{1,22}=1.76 ; P=0.2\right)$ of the quantity of organic matter they contained.

TABLE 1. Composition of soil and activity of water-extractable ice nuclei (WEIN) in soil in which painted turtles (Chrysemys picta) hatch and overwinter at four locales.

\begin{tabular}{|c|c|c|c|c|c|c|}
\hline \multirow[b]{2}{*}{ Variable } & \multicolumn{6}{|c|}{ Collection locale } \\
\hline & GL- 1 & GL-2 & APP & APP & $\mathrm{DL}$ & VNWR \\
\hline Sample origin & nest & nesting site & nest & nesting site & nesting site & nesting site \\
\hline No. samples & $12 \dagger$ & 7 & 4 & 8 & 3 & 1 \\
\hline Soil texture: & sand & sand & sand & sand & loamy sand & sand \\
\hline Organic content $(\%) \ddagger$ & 1.3 & 2.0 & 1.2 & 1.6 & 4.5 & 1.0 \\
\hline \multicolumn{7}{|l|}{ Nucleating activity $\left({ }^{\circ} \mathrm{C}\right) \S$} \\
\hline Sample minimum & $\ldots$ & $-5.0 \pm 0.01$ & $-11.2 \pm 0.6$ & $-12.5 \pm 1.5$ & $-5.6 \pm 0.1$ & $\cdots$ \\
\hline Sample maximum & $\ldots$ & $-4.5 \pm 0.1$ & $-3.4 \pm 0.1$ & $-5.4 \pm 0.04$ & $-5.4 \pm 0.1$ & $\cdots$ \\
\hline Pool, untreated & $-4.6 \pm 0.1$ & $-4.7 \pm 0.1$ & $-3.6 \pm 0.1$ & $-6.6 \pm 0.3$ & $-3.9 \pm 0.1$ & $-5.3 \pm 0.1$ \\
\hline Pool, autoclaved & $-12.2 \pm 0.4$ & $-12.8 \pm 0.5$ & $-16.4 \pm 0.4$ & $-12.1 \pm 0.5$ & $-13.9 \pm 0.5$ & $-9.5 \pm 0.2$ \\
\hline$t \|$ & 18.4 & 15.9 & 31.0 & 9.4 & 19.6 & 18.8 \\
\hline$P \|$ & $<0.0001$ & $<0.0001$ & $<0.0001$ & $<0.0001$ & $<0.0001$ & $<0.0001$ \\
\hline
\end{tabular}

Note: GL-1 and GL-2 were collected at Gimlet Lake, west-central Nebraska, USA; APP samples were from Algonquin Provincial Park, Ontario, Canada; DL is from Dewart Lake, Indiana, USA; and VNWR is from Valentine National Wildlife Refuge, north-central Nebraska, USA.

† Samples were collected and combined prior to the beginning of this study.

$\$$ Determined for soil combined, in equal amounts, from all samples collected at each locale.

$\$$ Activity of the WEIN is represented by the temperature of crystallization $\left(T_{c}\right)$ of soil washings prepared from each sample. Values are means $\pm 1 \mathrm{SE}$ based on $n=24$ values per group.

$\|$ Results of Student's $t$ test that mean $T_{\mathrm{c}}$ values for untreated and autoclaved pooled samples differed. 


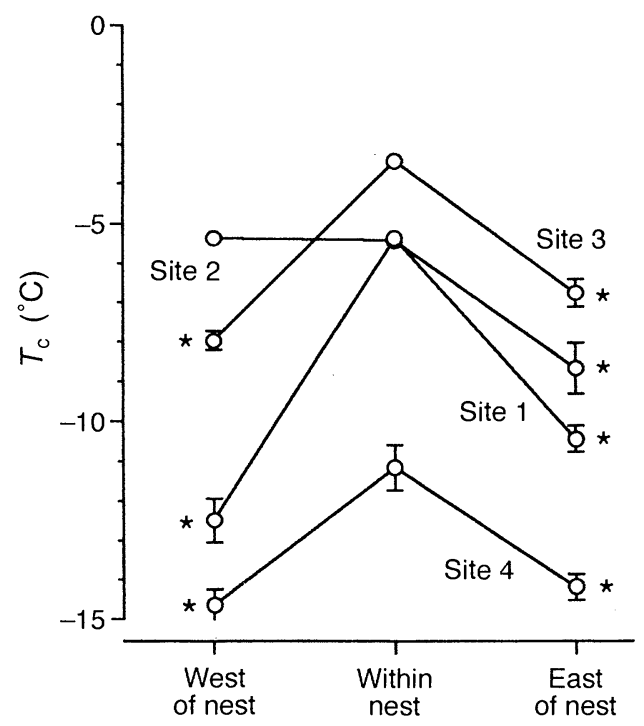

FIG. 5. Activity of water-extractable ice nuclei, as represented by temperature of crystallization $\left(T_{\mathrm{c}}\right)$ in washings of soil collected from four nests of the painted turtle (Chrysemys picta), and from a similar depth at locations $3 \mathrm{~m}$ west and 3 $m$ east of each nest. Each point represents a mean ( $\pm 1 \mathrm{SE}$ ) $T_{\mathrm{c}}$ based on $n=24$ values/group. Means identified by stars $(\star)$ differed statistically from the mean for the corresponding nest (Bonferroni test: $P<0.001$ ).

Activity of the WEIN in soil varied markedly among the 12 samples collected at APP (ANOVA: $F_{11.278}=$ 103.1; $P<0.0001$; Fig. 5). Four of these samples were of soil originating within egg-containing turtle nests, whereas the remaining eight samples were collected from locations $3.0 \mathrm{~m}$ distant, with a pair of such "satellite" samples associated with each nest. Ice-nucleating activity in soil sampled from the nest proper was generally higher than that in soil collected at the nest's satellite locations (Bonferroni test: $P<0.001$; Fig. 5). We reasoned that this outcome may have resulted because the soil collected from nest chambers (which was also used to incubate the eggs contained within them) had been exposed to eggshell fragments, embryonic membranes, and hatchlings prior to testing, whereas the satellite soil samples had been transferred to glass vials (and thus isolated from such contaminants) soon after collection. To address this possibility, we assayed the activity of nuclei in additional samples of soil that had been collected from the same four nests and, like the satellite samples, placed in closed glass vials shortly after collection. Analyses of the resulting data indicated that, as before, ice-nucleating activity differed $\left(F_{11,278}=153.2 ; P<0.0001\right)$ among the 12 samples, being substantially higher in the nest soil than in the soil collected at the corresponding nest's satellite locations (Bonferroni test: $P<0.001$ ). Because the nest soil used in this second analysis had been in contact with eggs for $\sim 8 \mathrm{wk}$ prior to sampling but was afterwards isolated from eggshell fragments, embryonic membranes, and hatchlings, we concluded that the pattern of higher nucleating activity in the soil inside (as compared with outside) turtle nests appears to be established prior to the hatching of eggs.

\section{Characterization of water-extractable ice nuclei in turtle nesting soils}

Ice-nucleating activity in washings of soil, combined from four egg-containing nests (APP), was strongly dependent on thermal history (ANOVA: $F_{5,138}=160.6$; $P<0.0001)$. Activity after sequential incubation of the soil at $20^{\circ}, 15^{\circ}$, and $10^{\circ} \mathrm{C}$ was approximately $-6^{\circ} \mathrm{C}$; however, subsequent exposure to $5^{\circ} \mathrm{C}$ triggered a marked increase in activity $\left(T_{\mathrm{c}}=-3.6^{\circ} \pm 0.06^{\circ} \mathrm{C}\right.$; Fig. $6)$. Nucleating activity was unaffected by further reducing the incubation temperature to $-2.5^{\circ} \mathrm{C}\left(T_{\mathrm{c}}=\right.$ $\left.-3.5^{\circ} \pm 0.09^{\circ} \mathrm{C}\right)$, although it was diminished by rewarming the soil to $10^{\circ} \mathrm{C}\left(T_{\mathrm{c}}=-4.1^{\circ} \pm 0.2^{\circ} \mathrm{C}\right.$; Bonferroni test: $P=0.0004)$.

Ice-nucleating activity in a washing prepared from GL-1 was diminished by serial dilution to $10^{-4}$ (ANO-

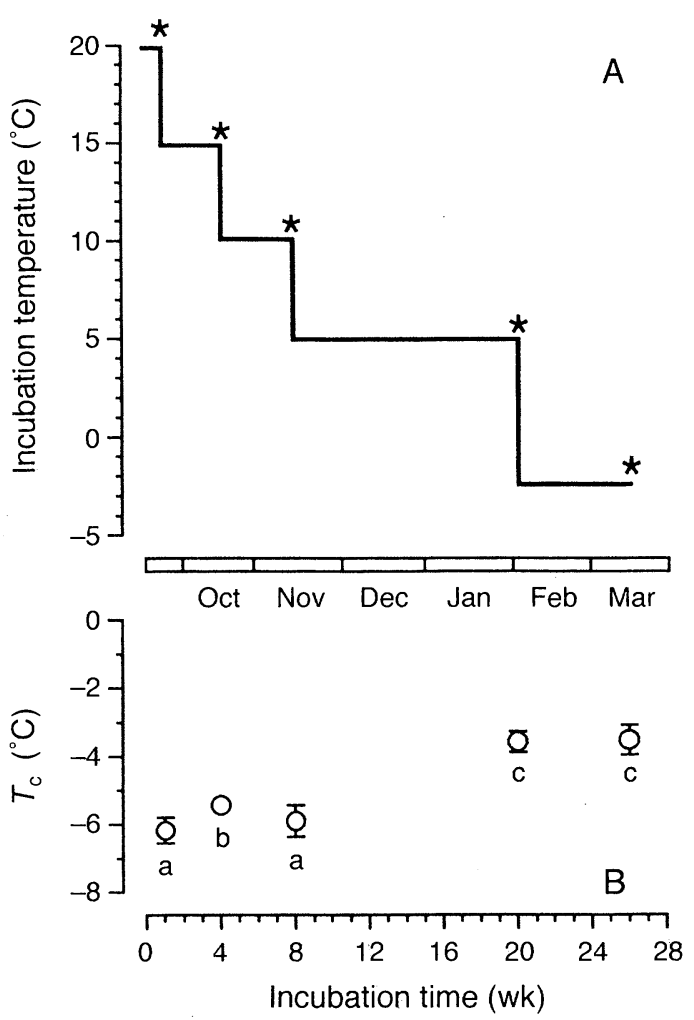

FIG. 6. Effect of progressive cold exposure on the activity of water-extractable ice nuclei in a sample of soil collected from nests of the painted turtle (Chrysemys picta). (A) Thermal history of the soil sample is depicted by the line; stars $(\star)$ indicate times when ice-nucleating activity was assayed. (B) Ice-nucleating activity of the soil sample as represented by temperature of crystallization $\left(T_{\mathrm{c}}\right)$ of soil washings. Each point represents mean ( $\pm 1 \mathrm{SE}) T_{\mathrm{c}}$ based on $n=24$ values/ group. Means identified by different lowercase letters differed statistically (Bonferroni test: $P=0.003$ ). 
TABLE 2. Ice-nucleating activity of water-extractable ice nuclei (WEIN) in soil collected from painted turtle (Chrysemys picta) nests and in a killed Pseudomonas syringae suspension, after various treatments.

\begin{tabular}{|c|c|c|}
\hline \multirow[b]{2}{*}{ Treatment } & \multicolumn{2}{|c|}{$T_{\mathrm{c}}\left({ }^{\circ} \mathrm{C}\right)$} \\
\hline & Nest soil & P. syringae \\
\hline Unfiltered (control) & $-5.0 \pm 0.06$ & $-2.3 \pm 0.04$ \\
\hline $\begin{array}{l}\text { Physical isolation } \\
\text { Filtrate } \\
10 \mu \mathrm{m} \text { pore } \\
5 \mu \mathrm{m} \text { pore } \\
0.2 \mu \mathrm{m} \text { pore }\end{array}$ & $\begin{array}{l}-5.0 \pm 0.06 \\
-5.1 \pm 0.06 \\
-5.4 \pm 0.07\end{array}$ & $\begin{array}{l}-2.4 \pm 0.04 \\
-2.5 \pm 0.05 \\
-6.8 \pm 0.07 \dagger\end{array}$ \\
\hline $\begin{array}{l}\text { Centrifugation } \\
540 \mathrm{~g} \\
48 \times 10^{3} \mathrm{~g} \\
48 \times 10^{4} \mathrm{~g}\end{array}$ & $\begin{array}{l}-5.0 \pm 0.07 \\
-5.0 \pm 0.05 \\
-5.4 \pm 0.001\end{array}$ & $\begin{array}{l}-2.4 \pm 0.06 \\
-2.7 \pm 0.04 \\
-2.8 \pm 0.001\end{array}$ \\
\hline $\begin{array}{l}\text { Physico-chemical denaturization } \\
\text { Heated } \\
65^{\circ} \mathrm{C} \text { for } 60 \mathrm{~min} . \\
95^{\circ} \mathrm{C} \text { for } 60 \mathrm{~min} .\end{array}$ & $\begin{array}{l}-5.4 \pm 0.05 \\
-7.2 \pm 0.07 \dagger\end{array}$ & $\begin{array}{l}-7.0 \pm 0.05 \dagger \\
-9.8 \pm 0.3 \dagger\end{array}$ \\
\hline $\begin{array}{l}\text { Autoclaved, } 120^{\circ} \mathrm{C}, 1.65 \mathrm{~kg} / \mathrm{cm}^{2} \text { for } 20 \mathrm{~min} \text {. } \\
\mathrm{HClO}_{4}, 7 \% \\
\quad \text { Blank } \neq\end{array}$ & $\begin{array}{l}-12.2 \pm 0.4 \dagger \\
-12.8 \pm 0.2 \dagger \\
-20.4 \pm 1.3 \dagger\end{array}$ & $\begin{array}{l}-17.5 \pm 0.6 \dagger \\
-10.5 \pm 0.08 \dagger\end{array}$ \\
\hline $\begin{array}{l}\mathrm{KOH}, 10 \% \\
\text { Blank }\end{array}$ & $\begin{array}{l}-12.8 \pm 0.2 \dagger \\
-19.6 \pm 0.4 \dagger\end{array}$ & $-20.1 \pm 0.9 \dagger$ \\
\hline $\begin{array}{l}\text { Urea, } 1 \mathrm{~mol} / \mathrm{L} \\
\text { Blank } \\
7 \mathrm{~mol} / \mathrm{L}\end{array}$ & $\begin{aligned}-5.5 & \pm 0.07 \\
-18.0 & \pm 0.4 \dagger \\
-6.6 & \pm 0.07\end{aligned}$ & $\begin{array}{l}-5.6 \pm 0.04 \dagger \\
-5.4 \pm 0.08 \dagger\end{array}$ \\
\hline $\begin{array}{l}\text { Proteolytic denaturization } \\
\text { Proteinase } \mathrm{K}, 100 \mu \mathrm{g} / \mathrm{mL} \S \\
\text { Blank }\end{array}$ & $\begin{array}{r}-5.1 \pm 0.04 \\
-19.4 \pm 0.6 \dagger\end{array}$ & $-3.2 \pm 0.04$ \\
\hline $\begin{array}{l}\text { Pronase, } 1 \mathrm{mg} / \mathrm{mL} \| \\
\text { Blank }\end{array}$ & $\begin{array}{r}-5.5 \pm 0.07 \\
-17.7 \pm 0.8 \dagger\end{array}$ & $-2.3 \pm 0.04$ \\
\hline
\end{tabular}

Notes: Nucleating activity is represented by temperature of crystallization $\left(T_{\mathrm{c}}\right)$ of soil washings or bacterial suspension. Means are shown \pm 1 SE $(n=24)$.

$\dagger$ Mean differed from the respective unfiltered control (Dunnett test: $P<0.01$ ).

$\$$ Blanks were prepared with sterilized, deionized water or reaction buffer (proteolytic denaturization assays). Mean \pm 1 SE $T_{\mathrm{c}}$ of sterilized, deionized water was $-17.0^{\circ} \pm 0.3^{\circ} \mathrm{C}$.

$\S$ Washing was prepared by substituting reaction buffer $(10 \mathrm{mmol} / \mathrm{L}$ Tris, $5 \mathrm{mmol} / \mathrm{L}$ EDTA, $0.5 \%$ SDS; $\mathrm{pH} 7.8)$ for water and was incubated for $2 \mathrm{~h}$ at $22^{\circ} \mathrm{C}$.

$\|$ Washing was prepared by substituting reaction buffer $(10 \mathrm{mmol} / \mathrm{L}$ Tris, $10 \mathrm{mmol} / \mathrm{L}$ EDTA, $0.5 \%$ SDS; $\mathrm{pH} 7.8)$ for water and was incubated for $2 \mathrm{~h}$ at $22^{\circ} \mathrm{C}$.

VA: $\left.F_{6,71}=46.1 ; P<0.0001\right)$. However, the washing retained full activity with dilution to $10^{-3}$, suggesting that the WEIN were highly concentrated. Activity decreased from approximately $-5^{\circ}$ to $-12.5^{\circ} \pm 1.5^{\circ} \mathrm{C}$ with another 10-fold dilution (Scheffé test: $P<$ 0.0001 ), and dilution of the washing to $10^{-5}$ effectively eliminated nuclei, as the mean $T_{\mathrm{c}}$ of this solution was indistinguishable (Bonferroni test: $P=0.5$ ) from that of sterilized, deionized water $\left(-14.7^{\circ} \pm 0.7^{\circ} \mathrm{C}\right)$.

Ice-nucleating activity in washings of GL-1 was unaltered by filtering or by centrifugation, suggesting that the nuclei are extremely small and of low specific gravity (Table 2). Partial deactivation was achieved by heating to $95^{\circ} \mathrm{C}$ (but not $65^{\circ} \mathrm{C}$ ), autoclaving, and treatment with strong acid and base. Treatment with urea caused a slight (albeit not statistically significant) loss of activity, but proteolytic denaturants were clearly ineffective under the assay conditions used. Similar results were obtained for the $P$. syringae suspension, except that this agent was more susceptible to heat and urea (Table 2).

\section{Occurrence of ice nuclei in natural habitats}

We found WEIN in habitats other than turtle nesting areas (Table 3). Washings of soil collected from agricultural fields in Wisconsin and South Dakota, and a deciduous woodlot in Ohio, nucleated at $-4^{\circ}$ to $-6^{\circ} \mathrm{C}$. Potent WEIN found in moss (Sphagnum sp.), collected from a bog in Ontario, were uncommonly resistant to autoclaving (Table 3). Surface water sampled from two aquatic habitats lacked potent ice nuclei, as did washings prepared from commercially obtained sand, clay, peat, and vermiculite.

\section{Discussion}

Unlike most cold-hardy ectotherms that survive exposure to subzero temperatures by either tolerating freezing or remaining supercooled, hatchling $C$. picta apparently utilize either strategy depending upon prevailing microenvironmental conditions. For example, whereas contact with damp nest soil (e.g., after rain or snow melt) promotes ice inoculation and a reliance on 
TABLE 3. Evidence for the presence or absence of water-extractable ice nuclei (WEIN) in some habitats in central North America and in other substances.

\begin{tabular}{|c|c|c|}
\hline \multirow[b]{2}{*}{ Sample } & \multicolumn{2}{|c|}{$T_{\mathrm{c}}\left({ }^{\circ} \mathrm{C}\right)$} \\
\hline & Untreated & Autoclaved \\
\hline Sterilized, deionized water (control) & $\ldots$ & $-17.0 \pm 0.3$ \\
\hline $\begin{array}{l}\text { Topsoil from agricultural field, Brookings Co., } \\
\text { South Dakota }\end{array}$ & $-5.7 \pm 0.03 \dagger$ & $-17.8 \pm 0.4 \ddagger$ \\
\hline $\begin{array}{l}\text { Topsoil from agricultural field, Waushara Co., } \\
\text { Wisconsin }\end{array}$ & $-5.4 \pm 0.05 \dagger$ & $-12.0 \pm 0.3 \dagger$ \\
\hline $\begin{array}{l}\text { Topsoil from mesic deciduous woodland, } \\
\text { Butler Co., Ohio }\end{array}$ & $-5.4 \pm 0.04 \dagger$ & $-13.3 \pm 0.2 \dagger$ \\
\hline $\begin{array}{l}\text { Moss (Sphagnum spp.) from bog, Parry Sound } \\
\text { District, Ontario }\end{array}$ & $-4.3 \pm 0.08 \dagger$ & $-5.6 \pm 0.05 \dagger$ \\
\hline $\begin{array}{l}\text { Surface water from ephemeral pond, Adams } \\
\text { Co., Ohio }\end{array}$ & $-12.4 \pm 0.3 \dagger$ & $-11.1 \pm 0.5 \dagger$ \\
\hline $\begin{array}{l}\text { Surface water from permanent pond, Adams } \\
\text { Co., Ohio }\end{array}$ & $-11.9 \pm 0.6 \dagger$ & $-12.1 \pm 0.7 \dagger$ \\
\hline Clay, volcanic origin & $-10.5 \pm 0.1 \dagger$ & $-10.3 \pm 0.2 \dagger$ \\
\hline Peat, horticultural grade & $-11.9 \pm 0.4 \dagger$ & $-15.9 \pm 0.4 末$ \\
\hline Sand, industrial grade & $-16.4 \pm 0.2$ & $-15.1 \pm 0.4$ \\
\hline Vermiculite, horticultural grade & $-17.9 \pm 0.5$ & $-15.5 \pm 0.4$ \\
\hline
\end{tabular}

Notes: Nucleating activity is represented by temperature of crystallization $\left(T_{\mathrm{c}}\right)$ of filtered washings prepared from solid materials or liquid samples. Means are shown \pm 1 SE $(n=24$ replicates $)$.

$\uparrow$ Mean differed from control (Dunnett test: $P<0.001$ ).

\$ Mean differed from that for untreated sample in same row (Scheffé test: $P<0.05$ ).

freeze tolerance (Costanzo et al. 1995b), supercooling is the more effective mode during periods of low ambient water potential, when the risk of inoculative freezing is reduced. Because hatchlings apparently survive freezing only if $T_{\mathrm{b}}$ remains $\geq-4^{\circ} \mathrm{C}$ (Storey et al. 1988, Claussen and Zani 1991, Churchill and Storey 1992, Costanzo et al. 1995b), supercooling may be crucial to surviving the occasional, transient exposures to more extreme temperatures occurring in nests during winter (Costanzo et al. 1995b, Packard and Packard 1995, Packard et al. 1997b). Our present work suggests that ice nuclei in the soil in which hatchling C. picta hibernate may constrain their ability to supercool and thus have implications for the cold hardiness of this species.

\section{Supercooling capacity of hatchling C. picta is exceptional among vertebrates}

In the absence of external ice nuclei, hatchling $C$. picta from all of the populations we studied super-. cooled extensively before spontaneously freezing (VNWR: $-13.3^{\circ} \pm 0.8^{\circ} \mathrm{C}, n=3$; APP: $-15.9^{\circ} \pm 1.5^{\circ} \mathrm{C}$, $n=7$; DL: $\left.-17.8^{\circ} \pm 0.3^{\circ} \mathrm{C}, n=14\right)$. One specimen, from DL, remained unfrozen until it had cooled to $-20^{\circ} \mathrm{C}$, the lowest $T_{\mathrm{c}}$ value reported for any vertebrate (Lee and Costanzo 1998). Incidental observations made during the course of this investigation suggested that hatchling $C$. picta can survive supercooling to at least $-15^{\circ} \mathrm{C}$.

In the absence of potent, endogenous ice nuclei, the supercooling capacity of vertebrates is inversely related to body mass and body water content (reviews: Costanzo and Lee 1995, Lee and Costanzo 1998). Consequently, hatchling turtles (and perhaps some small lizards; Halpern 1979, Costanzo et al. 1995a) may be unique among vertebrates in their ability to use supercooling to promote winter survival (but see Barnes 1989). The supercooling capacity of hatchling C. picta greatly exceeded that of three other turtle species (Fig. 7A), as well as other, similar-sized ectotherms (see Fig.
FIG. 7. Supercooling capacity of hatchlings of four turtle species plotted against (A) body mass and (B) body water content. Turtles were hatched and reared in vermiculite, cleaned of adherent particles, air dried of surface moisture, and cooled in otherwise empty, dry tubes. Each point represents the temperature of crystallization $\left(T_{\mathrm{c}}\right)$ of one turtle. Lines were fitted to data for turtles other than $C$. picta using simple regression (body mass, $y=1.26 x-14.4, r^{2}=$ $0.50, P<0.0001$; water content, $y=0.03 x-$ 20.8, $\left.r^{2}=0.26, P<0.01\right)$. Data are the same as those for control turtles as presented in Fig. 4 .

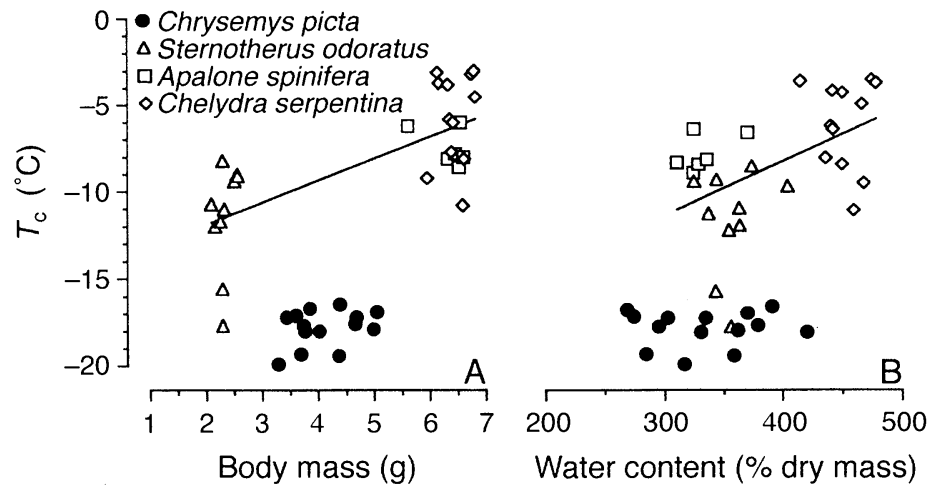


1 in Lee and Costanzo 1998) and, remarkably, was on par with that of a small water droplet (Fig. 1). The body water content of $C$. picta was relatively lower than that of the other species (Fig. 7B), although this difference alone cannot explain the exceptional supercooling capacity of these hatchlings. Perhaps this ability is promoted by behavioral or physiological adaptations, such as quiescence during cooling or the elimination or attenuation of endogenous ice nuclei. Hatchling $C$. serpentina and $A$. spinifera, which evacuate natal nests in autumn and hibernate underwater (Ernst et al. 1994), supercooled relatively less (Fig. 4). S. odoratus, which also overwinters underwater, supercooled to approximately $-11^{\circ} \mathrm{C}$, perhaps owing to its small body size and low water content; however, like C. picta, these turtles were susceptible to inoculation by environmental nuclei (i.e., $P$. syringae; Fig. 4). Perhaps $S$. odoratus overwinters outside the natal nest because it lacks freeze tolerance (J. Costanzo, J. Iverson, and $\mathrm{R}$. Lee, unpublished data) and, by virtue of its relatively small plastron (i.e., more exposed skin), may be at especially high risk of inoculative freezing and desiccation.

\section{Characteristics of ice nuclei in nesting soil}

It is unlikely that an animal's maximum, intrinsic capacity for supercooling, as demonstrated under idealized laboratory conditions, will be fully realized in nature, because contact with ice or other environmental nuclei (e.g., various silicates and other mineral particulates, proteins and other organic compounds, and certain microorganisms) may seed the freezing of body tissues (Bale 1987, Costanzo and Lee 1996, Lee and Costanzo 1998). The nucleation event is incompletely understood because the process involves fewer than several hundred molecules and is beyond the current limit of direct observation (Vali 1991). The activity of a given nucleator depends on its type, size, conformation, and association with other materials, as well as the physicochemical characteristics of the nucleating environment. Nuclei of biological interest generally exhibit activity at temperatures greater than $-10^{\circ} \mathrm{C}$ (Lee et al. 1995b, Lee and Costanzo 1998).

The sandy soil in which hatchling $C$. picta overwinter potentially harbors a variety of ice nuclei of both mineral (Mason and Maybank 1958, Roberts and Hallett 1968, Shen et al. 1977) and organic (Power and Power 1962, Fukuta 1966) classes. Ice nuclei occurring in natural soils may be complexes of inorganic and organic elements formed during decay of organic materials (Vali 1991). Nest soil from our study site in the sand hills of west-central Nebraska (GL-1) apparently contained more than one type of nuclei. Autoclaving the soil, thereby substantially reducing the activity of WEIN, only slightly diminished the nucleating activity in bulk soil samples (Fig. 1), apparently because this soil contained many autoclave-resistant nuclei (e.g., mineral particulates). Furthermore, the finding that au- toclaving the soil reduced, but did not eliminate, nucleating activity in the subsequently prepared washing (Table 1) suggests that this nest soil contained more than one type of WEIN. The autoclaving may have partially deactivated nuclei of a single type, or may have eliminated all nuclei of the most potent type, thus revealing the activity of nuclei belonging to another, relatively resistant (but less potent) class.

The soil nuclei of primary interest to us was extractable in water, active at approximately $-4^{\circ} \mathrm{C}$, and apparently quite small. Ice-nucleating activity was not diminished by passing the soil washing through a $0.2 \mu \mathrm{m}$ filter nor by high-speed centrifugation (Table 2). Transmission electron microscopy (TEM) revealed that these fully active filtrates lacked particles $>10 \mathrm{~nm}$. In contrast, $0.2-\mu \mathrm{m}$ filtrates of a $P$. syringae suspension contained numerous cell fragments that bear the icenucleating proteins (Phelps et al. 1986, Gurian-Sherman and Lindow 1995).

Some of our results suggest that the extractable agent in nest soil is organic, and possibly biogenic. For example, autoclaving, heating, and exposure of the nuclei to extremes of $\mathrm{pH}$ (albeit not treatment with urea or proteolytic enzymes) markedly reduced their activity (Table 2). These nuclei may be any of the various organic compounds, including certain amino acids (Power and Power 1962, Fukuta 1966), that exhibit nucleating activity in the same range and occur in the environment, independent of living cells. Additionally, given that various ice-nucleating bacteria ( $P$. syringae, $P$. fluorescens, P. putida, Enterobacter agglomerans) and fungi (Fusarium avenaceum) commonly occur in soils throughout North America (Hirano and Upper 1995), and the similarity between responses of the nuclei in soil and the killed $P$. syringae suspension in our characterization tests (Table 2), it is plausible that the WEIN in nesting soil are associated with these unique microorganisms. Although TEM revealed that active soil washings were devoid of recognizable cellular structures, the samples may have contained isolated nuclei that may be shed by microorganisms into the environment (Phelps et al.1986). Furthermore, the pattern of increase in nucleating activity of nest soil with cold conditioning (Fig. 6), and subsequent loss of activity upon rewarming, is reminiscent of the thermal sensitivity of the expression of genes encoding the nucleating proteins in some bacteria (Rogers et al. 1987, Gurian-Sherman and Lindow 1995).

We further probed the hypothesis that WEIN in nesting soil are associated with ice-nucleating microbes. Culture of soil washings prepared from GL-1 yielded a variety of unidentified colonies that, when isolated and assayed for nucleating activity (Vali 1971), gave largely negative results. However, given the propensity for ice-nucleating microbes to lose their activity in culture, this outcome is not definitive. Our preliminary study of these colonies with polymerase chain reaction (PCR) amplification techniques, using primers for the 
ice-nucleating proteins synthesized by $P$. syringae (ina $Z$ ) and $P$. fluorescens (ina $W$ ), indicated the presence of DNA sequences homologous to these primers. However, we caution that these results are tentative and that further tests are required to confirm the identity of these sequences and to attribute the activity of the WEIN to the putative presence of these microbes in nesting soil.

\section{Interaction between environmental ice nuclei and hatchling turtles}

The abundance, activity, and inoculation efficacy of various endogenous and exogenous nuclei are influential factors in the evolution of cold-hardiness strategies of ectothermic animals (Duman et al. 1995, Lee et al. 1995b, Costanzo and Lee 1996, Lee and Costanzo 1998). The efficacy by which environmental ice nuclei seed the freezing of body fluids depends on the animal's anatomical and morphological constitution (which may or may not pose barriers to the ingress of ice or other nuclei), ambient temperature, and physicochemical characteristics of the nucleating environment (Salt 1965, Gehrken 1992, Duman et al. 1995, Lee et al. 1995b, Packard and Packard 1995, Costanzo and Lee 1996). Environmental ice nuclei may access body fluids via orifices or wounds, or by directly transiting the integument. Whether such nuclei ultimately invade and nucleate the tissues depends, in part, on the relative sizes of the nuclei and the external openings (Gehrken 1992, Valerio et al. 1992).

The sandy soil in which $C$. picta typically nests undoubtedly contains an abundance of inorganic nuclei (Mason and Maybank 1958, Kumai 1976, Shen et al. 1977). Ice-nucleating activity in samples of autoclaved nest soil presumably reflects the presence of such nuclei (Fig. 1). However, these agents may be relatively ineffective at inoculating turtle tissues, because exposure of hatchlings to autoclaved nest soil influenced the supercooling capacity of few turtles (Fig. 2). In contrast, the very small WEIN readily inoculated turtles, even in the absence of environmental moisture (Fig. 2). Soil moisture clearly enhanced the communication of these nuclei (Fig. 3), perhaps by encouraging soil to lodge in the shell cavities of hatchlings and skin folds and ultimately bringing the nuclei into contact with the tissues.

\section{Resolving discrepancies in laboratory measurements of supercooling capacity}

Reported variation in the supercooling capacity of hatchling $C$. picta has fostered a misconception about the role of supercooling in the winter biology of this species. The finding that supercooling capacity is greater in hatchlings from north-central Nebraska (Packard and Packard 1995) than in hatchlings from several more temperate locales in the eastern United States (DePari 1988, Claussen and Zani 1991, Packard and Janzen 1996) and southern Canada (Storey et al. 1988, Storey et al. 1991, Churchill and Storey 1992) has promulgated the notion that this species exhibits adaptive, geographic variation in supercooling capacity. This contention was bolstered by the recent finding (Packard et al. 1997b) that hatchling C. picta indigenous to North Dakota, near the northern limit of distribution, also supercooled extensively $\left(T_{\mathrm{c}}<-9^{\circ} \mathrm{C}\right)$. However, despite its attractiveness from an evolutionary standpoint, this proposition has yet to be reconciled with the fact that other northern conspecifics (e.g., indigenous to westcentral Nebraska) supercooled minimally (Costanzo et al. 1995b).

A more parsimonious explanation for the disparity in reported supercooling capacities is that the turtles studied by one group of researchers were routinely incubated to hatching and subsequently kept in vermiculite, whereas turtles studied by most other workers hatched under natural conditions or were otherwise exposed to nest soil, before use in supercooling trials. Turtles in the former group supercooled extensively $\left(T_{\mathrm{c}}\right.$ typically lower than $-9^{\circ} \mathrm{C}$; Packard and Packard 1995, Packard and Janzen 1996, Packard et al. 1997b), whereas those in the latter group froze at high temperatures ( $T_{\mathrm{c}}$ typically $\geq-3^{\circ} \mathrm{C}$; DePari 1988 , Storey et al. 1988 , Claussen and Zani 1991, Storey et al. 1991, Churchill and Storey 1992, Costanzo et al. 1995b). (Paukstis et al. 1989 earlier studied hatchling C. picta from VNWR and found no differences in supercooling capacity between turtles incubated and reared in the laboratory and turtles hatched in the field; however, these results are equivocal because all specimens were long maintained in vermiculite before testing.) Our explanation for the disparity draws support from two points. First, by replicating the incubation and rearing protocol of G. C. Packard and co-workers, we observed extensive supercooling in hatchling $C$. picta representing not only the population studied by those investigators (VNWR), but also other populations, including one studied by $\mathrm{K}$. B. Storey and co-workers (APP; Storey et al. 1988, Storey et al. 1991, Churchill and Storey 1992). Secondly, discrepant results appeared in a single study reporting that hatchling $C$. picta collected from natural nests in Illinois supercooled much less than conspecifics from north-central Nebraska that had hatched and were maintained in vermiculite (Packard and Janzen 1996). The differences in supercooling capacities were attributed to interpopulational variation in cold hardiness, as putatively manifested by the presence of an "endogenous nucleator," in the Illinois turtles. However, our study, which yielded similar $T_{\mathrm{c}}$ values for $C$. picta hatched in nest soil, offers an alternative explanation. Hatching and rearing turtles on vermiculite that is heated (i.e., sterilized) during manufacture and apparently lacks extractable nuclei (Table 3 ), and meticulously cleaning and drying turtles before testing, likely exaggerates the supercooling capacity of hatchlings that undoubtedly contact ice nuclei in their winter microenvironment (Table 1). A more realistic model 
might consist of field-hatched turtles cooled in appropriately hydrated soil that has been obtained from the natal nest.

\section{Environmental ice nuclei: implications for turtle cold hardiness and survival}

Some freeze-tolerant ectotherms, particularly invertebrates, rely on ice nuclei in the body (e.g., specialized proteins) or in the environment (e.g., ice crystals) to initiate protective freezing. Nucleation at relatively high $T_{\mathrm{b}} \mathrm{s}$ promotes freeze tolerance by moderating the freezing rate and restricting ice to extracellular compartments (Lee 1991, Duman et al. 1995). The blood of hatchling $C$. picta reportedly contains nuclei that, as first described in specimens from APP, exhibits activity at $-7^{\circ}$ to $-8^{\circ} \mathrm{C}$ (Storey et al. 1991). However, the adaptive significance of these nuclei is equivocal because they nucleate plasma in vitro at temperatures lower than can be survived by frozen hatchlings (see Costanzo and Lee 1996). Our hatchlings, representing three distinct populations (VNWR, DL, and APP), supercooled extensively, giving no indication that such nuclei function in vivo. Indeed, given the similarities in characteristics between the blood nuclei (Storey et al. 1991) and the WEIN in nesting soil (e.g., sensitivity to heat and low $\mathrm{pH}$, apparent insensitivity to some proteases; Table 2), and the nonsterile method by which the blood was collected, it is possible that the samples were contaminated with soil nuclei (see Bale et al. 1989). Whether environmental nuclei, perhaps working synergistically with environmental water, can function in an adaptive capacity to promote survivable freezing (at $T_{\mathrm{b}} \mathrm{s}$ of $-4^{\circ} \mathrm{C}$ and above) is unknown.

There are few reports in which environmental ice nuclei other than ice itself have influenced the supercooling capacity of vertebrate ectotherms. Ice-nucleating bacteria were isolated from the gut of the wood frog, Rana sylvatica (Lee et al. 1995a); however, given the high susceptibility of anurans to ice inoculation, the role of these microbes in promoting freeze tolerance is uncertain (Costanzo and Lee 1996). One study (Packard and Packard 1995) reported $T_{\mathrm{c}} \mathrm{s}$ for hatchling $C$. picta inoculated by contact with a film of water $\left(-7.2^{\circ} \mathrm{C}\right)$, moist vermiculite $\left(-7.8^{\circ} \mathrm{C}\right)$, and moist sphagnum moss $\left(-4.6^{\circ} \mathrm{C}\right)$. Whereas turtles exposed to water alone or moist vermiculite likely were seeded by ice crystals forming on the skin, those in the latter group may have been inoculated by WEIN in the moss, which, as indicated by our results (Table 3), is uncommonly resistant to autoclaving and probably of inorganic origin.

Our data provide compelling evidence that ice nuclei in soil in which $C$. picta hatch, and ultimately overwinter, may compromise their ability to remain supercooled. Nevertheless, because hatchling C. picta contacting damp, sandy soils are highly susceptible to ice inoculation (Costanzo et al. 1995b, Costanzo and Lee 1996, Packard and Packard 1997), WEIN are probably of greatest consequence when soil water potential, and hence the risk of ice inoculation, is relatively low. Notably, turtles may be influenced by these nuclei even in the absence of environmental moisture (Fig. 2).

Given that hatchling $C$. picta tolerate freezing only at relatively high $T_{\mathrm{b}} \mathrm{s}$, the ability to remain supercooled appears to be critical to surviving the extreme temperatures occurring during some winters. Hatchlings typically experience minimum $T_{\mathrm{b}} \mathrm{s}$ in midwinter (Costanzo et al. 1995b, Packard 1997, Packard et al. 1997a), when the activity of WEIN in soil may be particularly high (Fig. 6), yet many survive to emerge from their nests in spring. How do hatchlings overwintering in intimate contact with nest soil, in the midst of such potent ice nuclei, remain supercooled? One answer may be that the transfer of nuclei to the body fluids is imperfectly efficient. The bimodal distribution of $T_{\mathrm{c}}$ values for turtles exposed to dry soil containing WEIN (Fig. 2) suggests an "all-or-none" response, in which nuclei accessed the body fluids of only some turtles. In addition, expression of the activity of these nuclei is influenced by the particular characteristics of the tissues that they contact (e.g., Bloch et al. 1963). Thus, activity of the WEIN expressed in the turtles may be substantially lower (approximately $-9^{\circ} \mathrm{C}$; Fig. 2) than that expressed in an aqueous medium $\left(-4.6^{\circ} \mathrm{C}\right.$; Table 1). Similarly, freezing of hatchling C. picta exposed to killed $P$. syringae, that were active in suspension at approximately $-2.5^{\circ} \mathrm{C}$, occurred only after they had cooled to approximately $-8^{\circ} \mathrm{C}$ (Fig. 4).

Another possibility is that turtles use behavioral means to limit contact with environmental ice nuclei. For example, by retracting its head and limbs within the shell, a hatchling may reduce its susceptibility to inoculation by environmental nuclei (Packard and Packard 1995). Also, the characteristic clustering of sibling $C$. picta during hibernation may diminish their contact with environmental nuclei, particularly for individuals occupying the center of the nest chamber. The degree of protection afforded by clustering likely depends on characteristics of the soil and whether the nest chamber is well formed and rigid (Breitenbach et al. 1984, DePari 1988) or loose and collapsed (Hartweg 1944, Packard et al. 1989). Nevertheless, this hypothesis may explain the differential survival of clutch mates overwintering within the same nest (Packard et al. 1989, Lindeman 1991, Packard 1997, Packard et al. $1997 a$ ), as well as the adaptive significance of producing larger clutches in northern locales (Iverson et al. 1993).

Our finding that nest soil exhibits relatively high levels of ice-nucleating activity as compared with soil at similar depths in adjacent areas is intriguing, albeit difficult to explain. Possibly the nuclei are more concentrated or active in soil at the specific sites where females opt to nest, or nuclei generally more prevalent at the soil surface are incorporated into the nest chamber during its construction. Surface soils, particularly 
those rich in organic matter, typically exhibit greater nucleating activity than deeper strata (Vali 1991). Alternatively, the activity of the nuclei may be enhanced after oviposition, perhaps in response to the female's traditional voiding of her bladder fluid over the completed nest (Ernst et al. 1994). Uric acid and allantoin, both components of turtle urine, are potent crystalloid nuclei (Fukuta 1966). All of these scenarios are consistent with our finding that activity of the WEIN is enhanced before the eggs hatch, and thus is unrelated to the presence in nests of broken eggshells, embryonic membranes, and hatchlings.

Variation in the activity of WEIN inside nests at a given locale (Table 1; Fig. 5) may reflect differential abundance of the nuclei, owing to variation in incident precipitation or local relief, if (as our protocol for preparing soil washings indicates) the nuclei may be leached by percolating water. Spatial heterogeneity in nucleating activity may account for observed variation in survival of hatchling $C$. picta overwintering in adjacent nests (DePari 1988, Packard et al. 1989, Packard 1997, Packard et al. 1997a), which occupy otherwise similar microenvironments. We found WEIN at each of the four nesting locales studied (Table 1). Geographic variation in the abundance and/or potency of nuclei among these locales is difficult to explain without knowing the identity and source of the agent(s); however, such variation may partly explain why hatchling C. picta survive nest temperatures lower than $-10^{\circ} \mathrm{C}$ in some areas (Woolverton 1963, DePari 1988, Packard et al. 1997a), but elsewhere perish in warmer nests (e.g., higher than $-6^{\circ} \mathrm{C}$; Packard et al. 1989, St. Clair and Gregory 1990). In addition to climatic factors, the presence of potent ice nuclei in nesting soil may thus impact the winter survival, demographics, and geographic distribution of $C$. picta. The occurrence of such nuclei in disparate habitats (Table 3 ) further suggests that they may have general implications for the cold hardiness of other ectotherms.

\section{ACKNOWLEDGMENTS}

We thank R. Brooks, M. Ellsbury, M. Finkler, M. French, J. Humphries, P. Kaufman, and M. Portelli for providing material, and C. Wentzel and C. Kostizen for technical assistance. R. Edelmann performed the TEM examination and L. Castrillo conducted the PCR assays. We thank R. McWilliams, R. Schaeffer, G. Vali, and S. Walker for discussing aspects of the research, and G. Breitenbach, D. Claussen, S. Coulson, M. Holmstrup, M. Wright, and an anonymous reviewer for commenting on the manuscript. Research was conducted in accordance with the IACUC of Miami University. This work was supported by grants from the National Science Foundation (IBN 9507437) and the National Institutes of Health (NIDDKD 1R15DK48067-01A1) to J. P. Costanzo.

\section{Literature Cited}

Bailey, R. M. 1949. Temperature toleration of gartersnakes in hibernation. Ecology 30:238-242.

Bale, J. S. 1987. Insect cold hardiness- an ecological perspective. Journal of Insect Physiology 33:899-908.

Bale, J. S., T. N. Hansen, and J. G. Baust. 1989. Nucleators and sites of nucleation in the freeze tolerant larvae of the gallfly Eurosta solidaginis (Fitch). Journal of Insect Physiology 35:291-298.

Barnes, B. M. 1989. Freeze avoidance in a mammal: body temperatures below $0^{\circ} \mathrm{C}$ in an Arctic hibernator. Science 244:1593-1595.

Bleakney, S. 1963. Notes on the distribution and life histories of turtles in Nova Scotia. Canadian Field Naturalist 77:6776.

Bloch, R., D. H. Walters, and W. Kuhn. 1963. Structurally caused freezing point depression of biological tissues. Journal of General Physiology 46:605-615

Breitenbach, G. L., J. D. Congdon, and R. C. van Loben Sels. 1984. Winter temperatures of Chrysemys picta nests in Michigan: effects on hatchling survival. Herpetologica 40: 76-81.

Churchill, T. A., and K. B. Storey. 1992. Natural freezing survival by painted turtles Chrysemys picta marginata and C. picta bellii. American Journal of Physiology 262:R530R537.

Claussen, D. L., and P. A. Zani. 1991. Allometry of cooling, supercooling, and freezing in the freeze-tolerant turtle Chrysemys picta. American Journal of Physiology 261: R626-R632.

Costanzo, J. P., C. Grenot, and R. E. Lee. 1995a. Supercooling, ice inoculation, and freeze tolerance in the European common lizard, Lacerta vivipara. Journal of Comparative Physiology B 165:238-244.

Costanzo, J. P., J. B. Iverson, M. F. Wright, and R. E. Lee. 1995b. Cold hardiness and overwintering strategies of hatchlings in an assemblage of northern turtles. Ecology 76: $1772-1785$

Costanzo, J. P., and R. E. Lee. 1995. Supercooling and ice nucleation in vertebrates. Chapter 12 in R. E. Lee, G. J. Warren, and L. V. Gusta, editors. Biological ice nucleation and its applications. American Phytopathological Society Press, St. Paul, Minnesota, USA.

Costanzo, J. P., and R. E. Lee. 1996. Mini Review: Ice nucleation in freeze-tolerant vertebrates. Cryo-Letters 17: 111-118

DePari, J. A. 1988. Overwintering in the nest chamber by hatchling painted turtles, Chrysemys picta, in northern New Jersey. Dissertation. Rutgers University, Newark, New Jersey, USA.

Duman, J. G., T. M. Olsen, K. L. Yeung, and F. Jerva. 1995. The roles of ice nucleators in cold tolerant invertebrates. Chapter 11 in R. E. Lee, G. J. Warren, and L. V. Gusta, editors. Biological ice nucleation and its applications. American Phytopathological Society Press, St. Paul, Minnesota, USA.

Ernst, C. H., R. W. Barbour, and J. E. Lovich. 1994. Turtles of the United States and Canada. Smithsonian Institution Press, Washington D.C., USA.

Etchberger, C., M. A. Ewert, B. A. Raper, and C. E. Nelson. 1992. Do low incubation temperatures yield females in painted turtles? Canadian Journal of Zoology 70:391-394.

Fukuta, N. 1966. Experimental studies of organic ice nuclei. Journal of Atmospheric Sciences 23:191-196.

Gehrken, U. 1992. Inoculative freezing and thermal hysteresis in the adult beetles Ips acuminatus and Rhagium inquisitor. Journal of Insect Physiology 38:519-524.

Gurian-Sherman, D., and S. E. Lindow. 1995. Differential effects of growth temperature on ice nuclei active at different temperatures that are produced by cells of Pseudomonas syringae. Cryobiology 32:129-138.

Halpern, E. A. 1979. Supercooling in the iguanid lizard Sceloporus jarrovi. Physiological Zoology 52:190-204.

Hartweg, N. 1944. Spring emergence of painted turtle hatchlings. Copeia 1944:20-22.

Hirano, S. S., and C. D. Upper. 1995. Ecology of ice nucleation-active bacteria. Chapter 3 in R. E. Lee, G. J. War- 
ren, and L. V. Gusta, editors. Biological ice nucleation and its applications. American Phytopathological Society Press, St. Paul, Minnesota, USA.

Iverson, J. B., C. P. Balgooyen, K. K. Byrd, and K. K. Lyddan. 1993. Latitudinal variation in egg and clutch size in turtles. Canadian Journal of Zoology 71:2448-2461.

Kumai, M. 1976. Identification of nuclei and concentrations of chemical species in snow crystals sampled at the South Pole. Journal of Atmospheric Sciences 33:833-841.

Lee, M. R., R. E. Lee, J. M. Strong-Gunderson, and S. R. Minges. 1995a. Isolation of ice-nucleating active bacteria from the freeze-tolerant frog, Rana sylvatica. Cryobiology 32:358-365.

Lee, R. E. 1991. Principles of insect low temperature tolerance. Chapter 2 in R. E. Lee and D. L. Denlinger, editors. Insects at low temperature. Chapman and Hall, New York, New York, USA.

Lee, R. E., and J. P. Costanzo. 1998. Biological ice nucleation and ice distribution in cold-hardy ectothermic animals. Annual Review of Physiology 60:55-72.

Lee, R. E., M. R. Lee, and J. M. Strong-Gunderson. 1993. Insect cold-hardiness and ice nucleating active microorganisms including their potential use for biological control. Journal of Insect Physiology 39:1-12.

Lee, R. E., G. J. Warren, and L. V. Gusta, editors. $1995 b$. Biological ice nucleation and its applications. American Phytopathological Society Press, St. Paul, Minnesota, USA.

Lindeman, P. V. 1991. Survivorship of overwintering hatchling painted turtles, Chrysemys picta, in northern Idaho. Canadian Field-Naturalist 105:263-266.

Mason, B. J., and J. Maybank. 1958. Ice-nucleating properties of some natural mineral dusts. Quarterly Journal of the Royal Meteorological Society 84:235-241.

Packard, G. C. 1997. Temperatures during winter in nests with hatchling painted turtles (Chrysemys picta). Herpetologica 53:89-95.

Packard, G. C., S. L. Fasano, M. B. Attaway, L. D. Lohmiller, and T. L. Lynch. 1997a. Thermal environment for overwintering hatchlings of the painted turtle (Chrysemys picta). Canadian Journal of Zoology 75:401-406.

Packard, G. C., and F. J. Janzen. 1996. Interpopulational variation in the cold-tolerance of hatchling painted turtles. Journal of Thermal Biology 21:183-190.

Packard, G. C., J. W. Lang, L. D. Lohmiller, and M. J. Packard. 1997b. Cold tolerance in hatchling painted turtles (Chrysemys picta): supercooling or freeze tolerance? Physiological Zoology 70:670-678.

Packard, G. C., and M. J. Packard. 1995. The basis for cold tolerance in hatchling painted turtles (Chrysemys picta). Physiological Zoology 68:129-148.

Packard, G. C., and M. J. Packard. 1997. Type of soil affects survival by overwintering hatchlings of the painted turtle. Journal of Thermal Biology 22:53-58.

Packard, G. C., M. J. Packard, P. L. McDaniel, and L. L. McDaniel. 1989. Tolerance of hatchling painted turtles to subzero temperatures. Canadian Journal of Zoology 67: $828-830$.

Paukstis, G. L., R. D. Shuman, and F. J. Janzen. 1989. Supercooling and freeze tolerance in hatchling painted turtles (Chrysemys picta). Canadian Journal of Zoology 67:10821084.

Phelps, P., T. H. Giddings, M. Prochoda, and R. Fall. 1986. Release of cell-free ice nuclei by Erwinia herbicola. Journal of Bacteriology 167:496-502.

Power, B. A., and R. F. Power. 1962. Some amino-acids as ice nucleators. Nature 194:1170-1171.

Roberts, P., and J. Hallett. 1968. A laboratory study of the ice nucleating properties of some mineral particulates. Quarterly Journal of the Royal Meteorological Society 94: $25-34$

Rogers, J. S., R. E. Stall, and J. M. Burke. 1987. Lowtemperature conditioning of the ice nucleation active bacterium, Erwinia herbicola. Cryobiology 24:270-279.

Salt, R. W. 1965. Factors influencing nucleation in supercooled insects. Canadian Journal of Zoology 44:117-133.

Shen, J. H., K. Klier, and A. C. Zettlemoyer. 1977. Ice nucleation by micas. Journal of the Atmospheric Sciences 34: 957-960.

St. Clair, R. C., and P. T. Gregory. 1990. Factors affecting the northern range limit of painted turtles (Chrysemys picta): winter acidosis or freezing? Copeia 1990:10831089.

Storey, K. B., D. G. McDonald, J. G. Duman, and J. M. Storey. 1991. Blood chemistry and ice nucleating activity in hatchling painted turtles. Cryo-Letters 12:351-358.

Storey, K. B., J. M. Storey, S. P. J. Brooks, T. A. Churchill, and R. J. Brooks. 1988. Hatchling turtles survive freezing during winter hibernation. Proceedings of the National Academy of Science USA 85:8350-8354.

Valerio, P. F., M. H. Kao, and G. L. Fletcher. 1992. Fish skin: An effective barrier to ice crystal propagation. Journal of Experimental Biology 164:135-151.

Vali, G. 1971. Quantitative evaluation of experimental results on the heterogeneous freezing nucleation of supercooled liquids. Journal of the Atmospheric Sciences 28: 402-409.

Vali, G. 1991. Nucleation of ice. Chapter 4 in G. Gotz, E. Meszaros, and G. Vali, editors. Atmospheric particles and nuclei. Akademiai Kiado, Budapest, Hungary.

Vali, G. 1995. Principles of ice nucleation. Chapter 1 in $\mathrm{R}$. E. Lee, G. J. Warren, and L. V. Gusta, editors. Biological ice nucleation and its applications. American Phytopathological Society Press, St. Paul, Minnesota, USA.

Woolverton, E. 1963. Winter survival of hatchling painted turtles in northern Minnesota. Copeia 1963:569-570. 